\title{
Scientific note on the first molecular detection of the acute bee paralysis virus in Brazilian stingless bees
}

\author{
Carlos Ueira-Vieira, Luciana Oliveira Almeida, Fernando Corrêa de Almeida, \\ Isabel Marques Rodrigues Amaral, Malcon Antônio Manfredi Brandeburgo, Ana Maria BonetTI
}

Laboratory of Genetics, Institute of Genetics and Biochemistry, Federal University of Uberlandia, Acre street, 2E building, room 226, Uberlandia, MG, Brazil

Received 18 May 2014 - Revised 11 December 2014 - Accepted 30 January 2015

virus / stingless bees / pathology / molecular diagnostics

Meliponiculture is a traditional activity in northern and northeastern Brazil, where it represents a complementary source of income (Ueira-Vieira et al. 2013). Indigenous Brazilian people have domesticated some species of stingless bees, such as the Melipona genus, due to their heartiness and honey production.

Rational rearing for commercialization of the Melipona scutellaris bee is common in northeastern Brazil. Their hive structure is different from honeybee mainly for lower number of workers than Apis mellifera. The honey and pollen are stored in a pot. The larval food is provisioned by workers, and after the queen lays eggs, the cell is totally closed by the worker. Therefore, there is no contact between the workers and larvae like in the honeybee. The caste determination mechanism in the Melipona genus is based on the interaction between environmental and genetic components, which is different from other bees (Kerr and Nielsen 1966).

Recently, our research group has received a large amount of information from beekeepers about a decrease in the stingless bee population as well as an increase in the number of dead stingless bees. Therefore, we performed reverse transcription polymerase chain reaction (RT-PCR) screening of seven viruses in M. scutellaris sampled from two meliponaries in Brazil.

Electronic supplementary material The online version of this article (doi:10.1007/s13592-015-0353-2) contains supplementary material, which is available to authorized users.

Corresponding author: C. Ueira-Vieira, ueira@ingeb.ufu.br

Manuscript editor: Yves Le Conte
Workers of M. scutellaris were collected from the meliponary at the Federal University of Uberlandia, Minas Gerais State (S 180 55'/W 450 17') ( $n=10$ hives) and a meliponary at Igarassu City, Pernambuco State $\left(07^{\circ} 50^{\prime} 03^{\prime \prime} \mathrm{S} 34^{\circ} 54^{\prime} 23^{\prime \prime} \mathrm{W}\right)$ ( $n=5$ hives). Only forager bees were used for molecular analysis, and they were collected after arriving back to the hive.

The total RNA was extracted from five stingless bees per hive using the TRIzol reagent (Invitrogen), according to manufacturer's recommendations. The total RNA was treated with DNAse enzyme (Promega) and used for reverse transcription using M-MLV reverse transcriptase (USB), according to the manufacturer's recommendations. The rp49 gene was used to test the quality of complementary DNA (cDNA).

Seven RNA viruses were analyzed using specific primers synthesized for each type of virus (see supplementary material, Table S1). DNA amplification of the different viruses was performed using Taq polymerase Platinum (Invitrogen) according to the manufacturer's instructions.

For in silico analysis, the CAP3 sequence assembly software was used to form a contig among sequencing repetitions (three replicate sequences for each amplicon). Phylogenetic analysis was performed using the Maximum Parsimony Method Software Mega 6 with the statistical analysis based on 1000 bootstrap replications.

After observing stingless bee death in our meliponary (Minas Gerais State in Brazil), we analyzed whether viruses were present in M. scutellaris stingless bees. Among the seven viruses screened by RT-PCR, positive results were only obtained for the acute bee paralysis virus (ABPV), and surprisingly, the infection was present in all 10 of the hives tested (Figure 1). The hives were observed weekly and the population was 


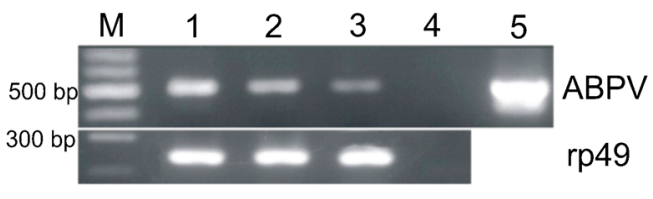

Figure 1. Detection of ABPV in Melipona scutellaris worker. $A$ amplification of partial genome viral fragment by RT-PCR, $M$ molecular marker, $1-3$ cDNA from workers bees, 4 negative control (without cDNA); 5 positive control. The gene $r p 49$ was used as control of cDNA quality.

decreasing until the queen's death, in about 6 months. On the other hand, five hives with healthy bees from Igarassu City, Pernambuco State, Brazil, sited almost $2000 \mathrm{~km}$ from the infected meliponary, were screened for all seven viruses, and the results were negative. Nevertheless, we cannot affirm if the death reason of the infected bees was the ABPV infection, because this stingless bee is very sensible to changes in environmental conditions.

One ABPV amplicon was cloned and sequenced. In silico analysis revealed $98 \%$ identity with ABPV from honeybees in Brazil (GenBank accession no. EU292210) and Uruguay (GenBank accession no. AY763414). The alignment of Melipona ABPV with the Israeli acute paralysis virus (IAPV) or the Kashmir bee virus (KBV) by blast 2 sequences showed only $71 \%$ of identity.

The ABPV phylogenetic tree from M. scutellaris showed basal branches for Melipona virus, and the branches were also derived from honeybee ABPV sequences from Europe and South America (Figure 2).

In honeybees, viruses can be horizontally transmitted by the mite Varroa destructor (Mockel et al. 2011). Melipona bees have good hygienic behavior, and one worker can help another to control the mite infestation.
The queen lays eggs on top of the massal food, and then, the cell broad is immediately closed off by workers, unlike honeybees that feed the larvae until the last larvae instar. Even if the mite enters the cell broad, it will likely die due to blockage of its life cycle. Thus, mites are unlikely to participate in virus transmission in Melipona .

Kleptoparasite phorid flies (Diptera, Phoridae), which are similar to flies belonging to the genera Pseudohypocera and Apiochaeta, Melittophora, are present in South and Central America. This parasite's larvae eat stingless bee pollen, honey, larval food, and the larvae itself. This behavior makes them a good candidate disease vector for stingless bee. Recently, Core et al. (2012) reported that larvae and adults of the phorid fly, Apocephalus borealis, from the USA were infected with deformed wing virus (DWV) and Nosema ceranae. These data suggest the phorid flies as potential viral vectors for stingless bees.

Some beekeepers use honeybee products, mainly pollen and/or honey syrup, as a supplemental food source for stingless bees. Honeybee viruses can be transmitted via the ingestion of infected honey or pollen (Chen et al. 2006; Singh et al. 2010). Moreover, the use of the honey substitutes, including syrup in supplemental food, could compromise the ability of bees to cope with pathogens as well as in A. mellifera (Mao et al. 2013).

Recently, some researchers have shown the wild pollinators from USA, Europe, and South America are infected with viruses, and that can be a serious problem for worldwide agriculture. Evison et al. (2012) analyzed by molecular methods the presence of the six viruses in pollinators from UK, and they found infection only by DWV in A. mellifera, Bombus terrestris, and Bombus pascuorum in bee species. Levitt et al. (2013) observed the presence of honeybee viruses in several arthropod species from the USA; as well, they detected the negative-strand RNA presence for DWV and IAPV, suggesting active replication of theses viruses in non-

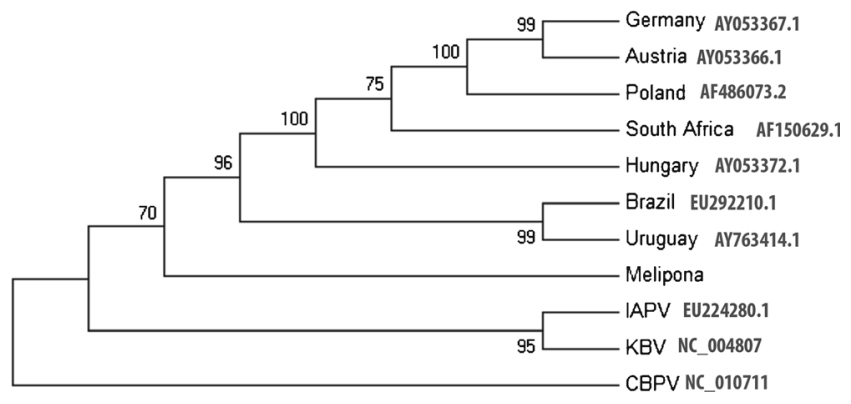

Figure 2. Phylogenetic analysis among ABPV found in M. scutellaris and honeybee viruses (ABPV, IAPV, and KBV) based on the Maximum Parsimony Method analysis with 1000 bootstrap replications. The chronic bee paralysis virus (CBPV) was used as outgroup. 
Apis species. In 2014, Furst et al. (2014) provide evidence for an emerging pathogen problem in wild pollinators in the UK. Reynaldi et al. (2013) showed for the first time viral co-infection in Bombus atratus from South America, by the black queen cell virus, sacbrood virus, and DWV.

Here, we reported the molecular detection of ABPV in M. scutellaris showing for the first time viral infection in stingless bees. However, we cannot assert that this infection is pathogenic to these bees. More studies should be performed for better comprehension of viral infection in Melipona .

\section{ACKNOWLEDGMENTS}

This work was supported by grants from Brazilian research agencies: FAPEMIG (CBB-APQ-01024-12 to $\mathrm{AMB}$ and $\mathrm{CBB}-\mathrm{APQ}-01952-13$ to $\mathrm{CUV}), \mathrm{CNPq}$ (445679/2014-0 to CUV), and CAPES.

\section{Scientifique note sur la première détection moléculaire du virus de la paralysie aigüe chez des abeilles sans aiguillon brésiliennes}

Eine Wissenschaftliche Notiz über die erste molekulare Identifizierung des akuten Bienenparalysevirus in einer brasilianischen Stachellosen Biene

\section{REFERENCES}

Chen, Y., Evans, J., Feldlaufer, M. (2006) Horizontal and vertical transmission of viruses in the honey bee, Apis mellifera. $\mathrm{J}$. Invertebr. Pathol. 92 (3), 152-159

Core, A., Runckel, C., Ivers, J., Quock, C., Siapno, T., et al. (2012) A new threat to honey bees, the parasitic phorid fly
Apocephalus borealis. PLoS ONE 7 (1), e29639. doi:10.1371/journal.pone.0029639

Evison, S.E.F., Roberts, K.E., Laurenson, L., Pietravalle, S., Hui, J., Biesmeijer, J.C., Smith, J.E., Budge, G., Hughes, W.O.H. (2012) Pervasiveness of parasites in pollinators. PLoS One 7 (1), e30641

Furst, M.A., McMahon, D.P., Osborne, J.L., Paxton, R.J., Brown, M.J.F. (2014) Disease associations between honeybees and bumblebees as a threat to wild pollinators. Nature 506, 364 368

Kerr, W.E., Nielsen, R.A. (1966) Evidences that genetically determined Melipona queens can become workers. Genetics 54(3), 859-866

Levitt, A.L., Singh, R., Cox-Foster, D., Rajotte, E., Hoover, K., Ostiguy, N., Holmes, E.C. (2013) Cross-species transmission of honey bee viruses in associated arthropods. Virus Res. 176, 232-240

Mao, W., Schuler, M.A., Berenbaum, M.R. (2013) Honey constituents up-regulate detoxification and immunity genes in the western honey bee Apis mellifera. Proc. Natl. Acad. Sci. U. S. A. $110(22), 8842-8846$

Mockel, N., Gisder, S., Genersch, E. (2011) Horizontal transmission of deformed wing virus: pathological consequences in adult bees (Apis mellifera) depend on the transmission route. J. Gen. Virol. 92 (2), 370-377

Reynaldi, F.J., Sguazza, G.H., Albicoro, F.J., Pecoraro, M.R., Galosi, C.M. (2013) First molecular detection of co-infection of honey bee viruses in asymptomatic Bombus atratus in South America. Braz. J. Biol. 73 (4), 797-800

Singh, R., Levitt, A.L., Rajotte, E.G., Holmes, E.C., Ostiguy, N., Vanengelsdorp, D., Lipkin, W.I., Depamphilis, C.W., Toth, A.L., Cox-Foster, D.L. (2010) RNA viruses in hymenopteran pollinators: evidence of inter-Taxa virus transmission via pollen and potential impact on non-Apis hymenopteran species. PLoS One 5(12), e14357

Ueira-Vieira, C., Nunes-Silva, C.G., Absy, M.L., Pinto, M.F.F.C., Kerr, W.E., Bonetti, A.M., Carvalho-Zilse, G.A. (2013) Pollen diversity and pollen ingestion in an Amazonian Stingless Bee, Melipona seminigra (Hymenoptera, Apidae). J. Apic. Res. 52, 137-178 